\title{
PELAYANAN KEMENTERIAN AGAMA TERHADAP PENGANUT AGAMA HINDU DI KABUPATEN LUWU UTARA PROVINSI SULAWESI SELATAN
}

\author{
The Services of Religion Minister Toward Hinduism \\ in Luwu Utara Regency, South Sulawesi
}

\author{
Muhammad Dachlan \\ Balai Penelitian dan Pengembangan Agama Makassar \\ Jl. A.P. Pettarani No. 72 Makassar \\ Email: muhammaddchlan@gmail.co.id
}

Naskah diterima tanggal 3 Maret 2014. Naskah direvisi tanggal 21 April 2014. Naskah disetujui tanggal 5 Mei 2014

\begin{abstract}
Abstrak
Tulisan ini mengulas mengenai pelayanan Kementerian Agama terhadap umat Hindu di Kabupaten Luwu Utara, Sulawesi Selatan. Penelitian ini bertujuan untuk mengetahui faktor-faktor apa sajakah yang mempengaruhi Kemenag Kabupaten Luwu Utara terkait pelayanan umat Hindu serta tanggapan umat Hindu terhadap pelayanan yang diberikan oleh Kemenag. Penelitian ini adalah penelitian kualitatif. Teknik pengumpulan dengan observasi dan wawancara sedangkan analisisnya menggunakan analisis deskriptif. Penelitian menemukan, Kemenag Kabupaten Luwu Utara melayani umat Hindu melalui mekanisme prosedural pada unit-unit kerja, khususnya Bimas Hindu. Salah satu program andalannya adalah UDG (Upsawa Darma Gita), yaitu lomba kidung-kidung kerohaniaan mulai tingkat desa hingga nasional. Dalam hal pelayanan, umat Hindu terkadang mengeluhkan lambatnya waktu pelayanan, tidak jelasnya prosedur, dan biaya pelayanan. Meski begitu, pelayanan yang diberikan Kemenag Kabupaten Luwu Utara telah sesuai mekanisme dan prosedural pelayanan keagamaan melalui Bimas Hindu.
\end{abstract}

Kata kunci: Kementerian Agama, pelayanan, agama Hindu

\begin{abstract}
This writing reviews about the religion minister service through Hinduism followers in North Luwu Regency, South Sulawesi. This research aims to find out the factors influencing the religion minister in North Luwu Regency in relation to the service for Hinduism and their opinion about the service given by Religion Minister. This is a qualitative research. The data collection technique used observation and interview, while the data analysis was descriptive analysis. The research found that the Religion Minister of North Luwu Regency serves the Hiduism through procedural mechanism in some work units, especially Bimas Hindu. One of the main programs is UDG (Upsawa Darma Gita), that is a religious song competition starting from village level through national. In terms of service, sometimes Hinduism followers coplain about the late of service time, unclear procedure and service cost. Even so, the service given by religion minister of North Luwu Regency has been sufficient to the mechanism and procedural of religion service through Bimas Hindu.
\end{abstract}

Keywords: religion minister, service, Hinduism

\section{PENDAHULUAN}

$\mathrm{P}$ ergerakan pertambahan jumlah penganut agama Hindu di Kabupaten Luwu Utara tidak terlepas dari upaya Pemerintah Pusat beberapa puluh tahun silam di masa Orde Baru, ketika sebahagian besar masyarakat pulau Bali diberdayakan tingkat ekonomi dan kesejahteraannya melalui program transmigrasi. Di Kabupaten Luwu Utara sendiri, program transmigrasi selanjutnya 
mendorong pertambahan jumlah umat Hindu dari waktu ke waktu. Lebih dari itu, umat Hindu rupanya sudah cukup diterima oleh masyarakat Kabupaten Luwu, hal mana dapat dilihat dari pemakaian simbol-simbol kebudayaan Bali pada berbagai bangunan dan fasilitas publik.

Cukup besarnya populasi penganut agama Hindu sebagaimana uraian di atas tentu saja membutuhkan strategi Kantor Kementerian Agama setempat dalam membina hubungan sosial dengan penganut agama lainnya, terutama Islam sebagai mayoritas. Beberapa alasan perlunya strategi tersebut karena sejauh ini penganut agama Hindu setempat seringkali melaksanakan kegiatankegiatan keagamaan dengan memanfaatkan ruang umum, kecuali Pura sebagai tempat ibadah khusus. Sebut saja Ogo-Ogo dan Ngaben (pembakaran mayat). Masyarakat penganut agama lain seringkali masih belum menerima pegelaran ritual keagamaan tersebut karena dianggap dapat mempengaruhi keadaan psikis orang sehingga memungkinkan dapat berpindah keyakinan.

Kegiatan ritual keagamaan tersebut selanjutnya dapat diangkat menjadi isu-isu yang sensitif memeta potensi konflik intern antar pemeluk agama lingkup Kabupaten Luwu Utara sebagaimana beberapa kejadian yang pernah terjadi. Bila kemudian dapat terselesaikan, harapan dari semua itu adalah tersedianya pelayanan agama yang adil merata tanpa ada perbedaan. Hasil obervasi lapangan, tertanggal 5-11 Maret 2013 menunjukkan bahwa, agar tercipta ketenteraman antar umat beragama khususnya penganut agama Hindu, dibutuhkan optimalisasi pelayanan agama dari Kantor Kementerian Agama setempat. Walaupun di saat yang sama, Kantor Kementerian Agama setempat telah menyusun rencana strategis pemberdayaan dan pembinaan kehidupan antar umat beragama melalui "gelar pawai budaya dan agama".

Berdasarkan uraian yang telah dikemukakan maka yang menjadi fokus permasalah dalam penelitian ini adalah mengapa pelayanan agama Hindu di Kantor Kementerian Agama lingkup Kabupaten Luwu Utara perlu di optimalkan?; Faktor apa yang mempengaruhi kualitas pelayanan keagamaan bagi penganut Agama Hindu?; Bagaimana tanggapan penganut agama Hindu Kabupaten Luwu Utara terhadap kualitas pelayanan yang diberikan Kantor Kementerian Agama?

Pelayanan yang dimaksud dalam penelitian ini adalah Kementerian Agama dalam melayani
Publik. Dalam keputusan Menpan Nomor 63 tahun 2004 membedakan jenis pelayanan menjadi tiga kelompok, yaitu: a) Kelompok pelayanan administratif, yaitu pelayanan yang menghasilkan berbagai bentuk dokumen resmi yang dibutuhkan oleh publik, misalnya status kewarganegaraan, sertifikat kompetensi, kepemilikian atau penguasaan terhadap suatu barang dan sebagainya. Dokumen-dokumen ini antara lain Kartu Tanda Penduduk (KTP), akte pernikahan, akte kelahiran, surat kematian, Buku Pemilik Kendaraan Bermotor (BPKB), Surat Izin Mengemudi (SIM), Surat Tanda Nomor Kendaraan Bermotor (STNK), Izin Mendirikan Bangunan (IMB), paspor, sertifikat kepemilikan/penguasaan tanah dan sebagainya. b) Kelompok pelayanan barang yaitu pelayanan yang menghasilkan berbagai bentuk/jenis barang yang digunakan oleh publik, misalnya jaringan telepon, penyediaan tenaga listrik, air bersih dan sebagainya. c) Kelompok pelayanan jasa yaitu pelayanan yang menghasilkan berbagai bentuk jasa yang dibutuhkan oleh publik, misalnya pendidikan, pemeliharaan kesehatan, penyelenggara.

Pelayanan keagamaan yang dilakukan pemerintah, ternyata masih menuai sorotan dari sebagian pemeluk agama minoritas. Padahal, tujuan dari visi dan misi Kementerian Agama 2010-2014, adalah "Terwujudnya masyarakat Indonesia taat beragama, rukun, cerdas, mandiri, dan sejahtera lahir batin." visi dan misi ini kemudian dipertegas lagi pada poin 1 dan 2, yakni (1) meningkatkan kualitas kehidupan beragama dan (2), meningkatkan kualitas kerukunan umat beragama (Renstra Badan Litbang dan Diklat Kemenag RI, 2010).

Fungsi pemerintah dalam pelayanan publik menurut Sutopo dan Adi Suryanto (2009:9) adalah envirotmental servis (pelayanan lingkungan), development servis (pelayanan pengembangan), dan protective service (perlindungan).

Pelayanan publik atau pelayanan umum dapat diartikan sebagai segala bentuk jasa pelayanan, baik berbentuk barang maupun jasa publik. Pelayanan publik ini pada dasarnya merupakan tanggung jawab dan dilaksanakan oleh instansi pemerintah, baik di pusat dan daerah, sebagai upaya memenuhi kebutuhan masyarakat berdasarkan ketentuan peraturan perundang-undangan (http:// id.wikipedia.org/wiki/pelayanan_publik, diakses pada 21 Desember 2012). Di Indonesia, pelayanan publik sering juga diartikan sebagai publik service (Ratminto dan Atik SP, 2007: 4). Untuk melihat keberhasilan suatu pelayanan keagamaan, setidaknya 
ada lima indikator, seperti yang dikemukakan Fitsimmons, yaitu: Realibility; yakni pemberian pelayanan tepat sasaran. Tangibles; adalah kualitas sumber daya manusia dan sumber daya lainnya yang memadai. Responsiveness; yakni pelayanan secara tepat. Assurance; yakni perhatian terhadap etika dan moral dalam memberikan pelayanan, dan Empathy; adalah kemauan untuk memahami dan mengerti keinginan dan kebutuhan konsumen (Pat Badrun, dkk, 2008:6).

\section{METODE PENELITIAN}

Penelitian ini dilaksanakan di kabupaten Luwu Utara. Teknik Pengumpulan Data dalam penelitian ini: Observasi. Observasi yang bertujuan untuk menggali informasi awal tentang sasaran penelitian. Data dan informasi yang diperoleh selanjutnya digunakan untuk pendalaman masalah. Wawancara. wawancara mendalam (Indept Interview). Wawancara dilakukan untuk menggali informasi sedalam-dalamnya tentang bentuk dan kualitas layanan agama Hindu yang diselenggarakan oleh Kantor Kementerian Agama Kabupaten Luwu Utara. Wawancara ditujukan kepada pihak-pihak terkait seperti: Kepala Kantor Agama Kabupaten Luwu Utara, Bimas Hindu Kantor Agama Luwu Utara, tokoh masyarakat dan pemuka agama Hindu, maupun penganut agama Hindu perseorangan yang tersebar di 11 Kecamatan. Beberapa aspek penting yang digali dalam wawancara antara lain: dinamika perkembangan kehidupan beragama penganut agama Hindu lingkup Kabupaten Luwu Utara, program dan kegiatan pemberdayaan dan pembinaan kehidupan beragama bagi penganut agama Hindu, bentuk dan kualitas layanan agama Kantor Kementerian Agama setempat, mekanisme dan prosedur usul kegiatan keagamaan yang diajukan penganut agama Hindu, dan tanggapan atas kualitas pelayanan yang diterima. Dokumentasi. Teknik Dokumentasi pada prinsipnya merupakan suatu upaya untuk mengkoleksi kebutuhan data, konsep, teori maupun informasi yang dapat diperoleh dari referensi bahan bacaan, laporan Renstra Kantor Kementerian Agama Kabupaten Luwu Utara, maupun data populasi umat Hindu yang masih relevan dengan tujuan yang diharapkan dari penelitian ini.

Pemilihan informan dilakukan secara purposive, yakni memilih informan yang berkaitan erat dengan tema penelitian. Informan yang dipilih adalah mereka yang mudah diajak bicara, mengerti tentang informasi yang peneliti butuhkan, dan yang senang diajak bekerja sama (Edraswara, 2006:121). Melihat dari karakteristik permasalahan dan data yang akan diperoleh melingkupi pelayanan keagamaan Kementerian Agama terhadap umat Hindu, maka digunakan teknik analisis deskriptif kualitatif model Miles dan Huberman (1994:12). Model analisis tersebut menekankan pada empat tahapan pokok, yaitu: (1) pengumpulan data/ data collection, diperoleh dari kegiatan observasi, wawancara dan dokumentasi (2) reduksi data/data reduction, yaitu merangkum, memilih dan memilah hal-hal pokok lalu menfokuskan pada hal-hal penting dari sejumlah data yang telah diperoleh (3) penyajian data/data display, yaitu menyajikan data yang telah direduksi sehingga mudah dipahami, dan (4) penarikan kesimpulan/conclution, yaitu totalitas hasil interpretasi yang didasarkan analisis data untuk menjawab permasalahan penelitian. Kemudian, analisis penelitian ini tidak hanya dijelaskan dengan menggunakan kalimat-kalimat yang dideskripsikan, tetapi sedapat mungkin memberi kejelasan obyek penelitian (Moleong, 2000:36).

\section{PEMBAHASAN \\ Setting Sosial Umat Hindu di Kabupaten Luwu Utara}

Eksistensi keberadaan suatu masyarakat tidak dapat dipisahkan dari aspek kesejarahan. Kesejarahan dalam arti, kapan dan bagaimana masyarakat itu ada dan berkembang di satu wilayah teritori tertentu. Demikian halnya penganut agama Hindu yang saat ini berdomisili di lingkup wilayah pemerintahan daerah Kabupaten Luwu Utara.

Pasca pemekaran wilayah Kabupaten Luwu, praktis Kabupaten Luwu Utara dengan ibukota kabupaten Masamba menjadi satu wilayah pemerintahan daerah otonom yang berhak mengurus rumah tangganya sendiri, yang sebelumnya hanyalah sebuah wilayah kecamatan di Kabupaten Luwu. Dengan demikian, geliat pertumbuhan dan perkembangan aspek-aspek berkehidupan secara sosial, ekonomi, politik, agama, kesehatan, pendidikan dan bentuk tanggung jawab publik lainnya terus menunjukkan progres yang cukup baik.

Dengan luas wilayah 7.502.58 kilometer persegi, Kabupaten Luwu Utara terdiri dari 11 kecamatan dan 23 desa, dengan persebaran populasi penduduk mencapai 287.666 orang. Dari sebelas kecamatan tersebut, setidaknya terdapat 5 kecamatan yang menjadi titik konsentrasi umat Hindu, yaitu: Kecamatan Bone-Bone, Kecamatan 
Sukamaju, Kecamatan Mappadeceng, Kecamatan Malangke, dan Kecamatan Baebunta (Luwu Utara dalam Angka, 2010).

Kabupaten Luwu Utara merupakan satu dari sekian daerah pemekaran baru, maka pergerakan dan mobilisasi sosial, ekonomi dan agama sebagai pijakan dasar sebuah masyarakat cukup dinamis. Terlebih dengan adanya keberadaan umat Hindu, yang jauh hari telah berada di wilayah itu sejak program transmigrasi nasional dimasa pemerintahan Orde Baru. Berdasarkan hal tersebut, maka dapat dikatakan bilamana masuk dan berkembangnya jumlah penganut agama Hindu di Kabupaten Luwu Utara bukan semata-mata karena pertumbuhan populasi manusianya, tetapi juga bagian dari dampak keberhasilan program transmigrasi tersebut. Bahwa keberadaan umat Hindu di Kabupaten Luwu Utara mampu memberi warna baru dalam kehidupan sosial masyarakat yang nota bene berada dalam mayoritas suku bangsa Luwu yang cukup kuat memegang teguh ajaran agama Islam sebagai agama leluhur.

Namun demikian, data dan fakta menunjukkan bilamana penganut agama Hindu di Kabupaten Luwu Utara perlu mendapat perhatian serius mengingat persebara dan penganutnya juga berada pada sebelas wilayah kecamatan yang ada, terutama pada wilayah sentra pertanian dan perkebunan yang selama ini menjadi daya dukung utama pertumbuhan ekonomi Kabupaten Luwu Utara terhadap daerah-daerah sekitarnya, termasuk jangkauan pasarnya ke Kota Makassar. Suatu kondisi yang tentu saja cukup resisten dengan isu-isu konflik syara yang sewaktu-waktu bisa saja menyeruak ke permukaan sebagaimana beberapa kasus konflik horizontal umat Hindu sebagai minoritas dengan umat Islam sebagai mayoritas.

Untuk memberikan gambaran jelas tentang keadaan rill umat Hindu di Kabupaten Luwu Utara, sebagaimana data dan informasi yang dikumpulkan dari Unit Penyelenggara Bimas Hindu Kantor Kementerian Agama setempat, yaitu: jumlah rohaniawan Hindu sebanyak 44 orang, sarana ibadah atau pura sebanyak 53 , total penganut Hindu sebanyak 10330 orang dengan rincian perempuan sebanyak 4816 orang dan laki-laki sebanyak 5514 orang.

Hal penting lainnya terkait urgenitas dinamika kehidupan sosial umat Hindu adalah eksistensi keberadaan komponen pendukung lain yang memampukan mereka bisa terus berkembang dan beradaptasi dengan perkembangan kehidupan di lingkup wilayah setempat adalah dengan melihat distribusi jumlah guru agama Hindu sebanyak 38 orang.

\section{Bentuk dan Kualitas Layanan Kantor Kementerian Agama Kabupaten Luwu Utara terhadap Penganut Agama Hindu}

Pelayanan pemerintah kepada masyarakat pada hakikatnya didasarkan pada prinsip-prinsip kerja yang ditata kelola secara terbuka (transparan), dapat dipertanggungjawabkan (accuntabel), dan bersih (cleaness) tanpa didasari tendensi tertentu, apalagi bermuatan politis, ras maupun agama. Oleh karena itu, pelayanan keagamaan Kementerian Agama juga perlu melakukan hal serupa, khususnya lingkup Kabupaten Luwu Utara sebagai lokus utama dalam penelitian ini.

Belajar beberapa kepemimpinan kantor Kementerian Agama pada periode pemerintahan sebelum ini, Muchlis Chalid selaku Kandepag Luwu Utara coba mengurai dinamika kehidupan sosial dan keberagamaan masyarakat Luwu Utara cukup terjalin baik dalam satu hubungan kohesional. Dalam arti bahwa, tercipta satu rasa saling memiliki ikatan kesetiakawanan sosial yang kuat antar pemeluk agama, tak terkecuali panganut agama Hindu sekalipun. Sebagai daerah yang memiliki keberagaman yang cukup tinggi ditinjau dari aspek sosioantropologisnya, Luwu Utara dapat dikatakan sebagai Indonesia Mini. Sebab keberadaan orang dari berbagai suku bangsa dan agama tampak jelas, mampu mencitrakan ketenteraman sosial karena tidakadanya upaya dari setiap kelompok masyarakat untuk menunjukkan dominasi antara mayoritas maupun minoritas. Dalam keadaan yang serba heterogen tersebut, pluralisme justru memperkuat integritas sosial masyarakat di Kabupaten Luwu Utara yang tersebar dalam sebelas kecamatan.

Walaupun heterogenitas masyarakat itu tidak dapat dipisahkan dari isu-isu keretakan jalin sosial melalui saluran konflik (kelompok, agama dan kepercayaan), setidaknya sejauh ini keseluruhan kemungkinan itu dapat ditangani dengan baik. Sebagai contoh, pelaksanaan Ogo-Ogo yang masih belum mendapat tempat penuh dari kelompok agama mayoritas (Islam) sebab kurangnnya sosialisasi kegiatan penggunaan ruang umum. Namun demikian, kegiatan itu tidak serta merta menciptakan bias politis. Rupanya, hal tersebut di dukung oleh kemampuan internal masyarakat atas kesadaran memperkuat resistensi budaya setempat. 
Untuk menghindari kemungkinan lahir dan berkembangnya potensi konflik, kantor Kementerian Agama Kabupaten Luwu Utara selaku otoritas di bidang terkait, mengupayakan banyak kegiatan sosial keagamaan, salah satunya dengan memaksimalkan temu tokoh lintas agama se-Kabupaten Luwu Utara. Duduk bersama guna membahas perkembangan isu-isu dan upaya solusi yang sewaktu-waktu dapat melanda keberagaman entitas yang ada.

Khusus program-program pengembangan dan pembinaan kehidupan beragama umat Hindu, antara lain dengan melaksanakan pawai budaya keagamaan. Termasuk di dalamnya lomba nasional tembang/kidung keagamaan yang akan dikonsentrasikan di Kabupaten Luwu awal tahun 2014. Kandepag Luwu Utara ini bahkan dengan tegas menguraikan bilamana kegiatan tersebut merupakan satu terobosan besar yang perlu menjadi perhatian bersama, bukan saja Kantor Kementerian Agama setempat, tetapi juga pemerintah daerah bahkan bila perlu pemerintah pusat sekalipun. Bukan tak mungkin dan beliau sangat optimis bila kegiatan itu merupakan salah satu prestasi dan keberhasilan Kementerian Agama secara umum dalam memberikan pelayanan keagamaan bagi umat-umat beragama.

Temuan di atas mengindikasikan bilamana Kantor Kementerian Agama Kabupaten Luwu Utara (unsur pimpinan) memahami baik penerapan prinsip-prinsip pelayanan publik sebagaimana tertuang dalam Keputusan Menpan No. 63 Tahun 2003. Dalam Keputusan Menpan tersebut ditegaskan bahwa untuk meningkatkan kualitas pelayanan publik, maka penyelenggaraan pelayanan harus memenuhi beberapa prinsip sebagai berikut: kesederhanaan, kejelasan, kepastian waktu, akurasi, keamanan, tanggungjawab, kelengkapan sarana dan prasarana, kemudahan akses, kedisiplinan, kesopanan dan keramahan, serta kenyamanan.

Dari uraian sebelumnya, maka wujud pelayanan keagamaan Kantor Kementerian Agama Kabupaten Luwu Utara dapat dikelompokkan pada satu pola institusional yang diharapkan mampu menjadi usaha sadar kolektif umat beragama setempat keluar dari kemungkinan lahir dan berkembangnya konflik horizontal di tengah-tengah masyarakat dalam berkehidupan sehari-hari.

Dalam perspektif pelayanan publik, strategi pelayanan di atas pada akhirnya selaras dengan muatan isi Kepmenpan Nomor 63/KEP/M. PAN/7/2003 dimana dijelaskan bahwa "pelayanan publik sebagai segala kegiatan pelayanan yang dilaksanakan oleh penyelenggara pelayanan publik sebagai upaya pemenuhan kebutuhan penerima pelayanan maupun pelaksanaan ketentuan peraturan perundang-undangan". Dengan demikian, komponenutamadalam pemberian pelayanan publik tersebut dapat diukur dari seberapa besar penerapan pemberian pelayanan secara prima kepada penerima pelayanan dengan beberapa prinsip penting yang harus terpenuhi, yaitu: (1) prinsip penyelenggaraan layanan publik yang dikelola secara terbuka, dalam arti transparansi pelayanan harus berimbas pada tersentuhnya seluruh masyarakat yang membutuhkan layanan (2) prinsip akuntabilitas, yaitu suatu upaya pertanggungjawaban pelaksanaan pelayanan publik sebagaimana telah diatur dalam sistem perundang-undangan dan ketentuan hukum lainnya (3) kondisional, yaitu wujud pelayanan yang disesuaikan dengan tingkat kebutuhan dan urgenitas pemberi dan penerima layanan secara partisipatif yang berpegang pada nilai efektivitas dan efisiensi keterlaksanaan layanan (4) partisipatif, yaitu pelayanan yang dapat mendorong peran serta masyarakat dalam penyelenggaraan pelayanan publik atas dasar aspirasi, kebutuhan dan harapan masyarakat (5) kesamaan hak, yaitu pelayanan yang tidak melahirkan tindakan diskriminatif, baik dari aspek politik dan pemerintahan, agama, ras dan suku bangsa, golongan maupun status sosial tertentu, serta (6) keseimbangan hak dan kewaiban, yaitu pelayanan yang mempertimbangkan aspek keadilan sosial antara pemberi dan penerima layanan.

Tidak dapat dipungkiri bahwa, Indonesia sebagai negara yang tengah berkembang aspek kesejahteraan masyarakat cukup bergantung pada kemampuan mereka mendapat akses dan kemampuan untuk dapat menggunakan pelayanan publik. Akan tetapi permintaan akan pelayanan tersebut biasanya jauh melebihi kemampuan pemerintah untuk dapat memenuhinya.

Mencermati uraian di atas, perspektif psikososiologis pelayanan publik secara subtantif dapat dipahami melalui pembentukan perilaku yang sengaja disasarkan pada usaha sadar secara kondisional, pengertian dan pemodelan.

Berdasarkan uraian terdahulu maka dapat ditarik kesimpulan bahwa, transparansi, akuntabilitas, kondisionalisasi, partisipatif, kesamaan hak dan keseimbangannya dengan kewajiban pemberi dan penerima pelayanan publik adalah mutlak dilaksanakan untuk mencapai tujuan pembangunan masyarakat beragama di Kabupaten Luwu Utara. 
Faktor-faktor yang Memengaruhi Kualitas Pelayanan Keagamaan di Kabupaten Luwu Utara

I Ketut Sukarna menjelaskan bahwa, penganut agama Hindu sangat menjunjung tinggi budaya. Dimana pun mereka berada, selain mereka membawa kebudayaan sendiri, budaya daerah lain tetap di hargai. Pasca kedatangan masyarakat Bali melalui program transmigrasi di tahun 80 -an, selanjutnya tersebar di 22 desa se-Kabupaten Luwu Utara. Dalam perkembangannya, populasi terbesar umat Hindu berada di Kecamatan Mappadeceng (4047 orang), Sukamaju (4450 orang), dan BoneBone (1001 orang).

Pelayanan Kantor Kementerian Agama Luwu Utara terhadap umat Hindu tentu saja melalui mekanisme prosedural pada unit-unit kerja khususnya Bimas Hindu, untuk koordinasi sekaligus menjembatani harapan-harapan bentuk pelayanan yang dibutuhkan umat Hindu. Khusus bentuk pelayanan keagamaan, Kandepag Luwu Utara tidak memilih-milih. Artinya, setiap agama mendapat fasilitas pelayanan yang sama, termasuk umat Hindu. Oleh karena itu, kualitas pelayanan yang diberikan tidak berbeda antar satu agama dengan agama yang lain.

Salah satu program unggulan dalam memberdayakan kehidupan beragama Hindu lingkup Luwu Utara adalah melaksanakan UDG (Upsawa Darma Gita), yaitu lomba kidung-kidung kerohanian dari tingkat desa, kecamatan, kabupaten, provinsi sampai nasional. Dalam enam bulan terakhir, telah dimatangkan rencana kegiatan UDG tingkat nasional yang dilaksanakan di Kabupaten Luwu Utara. Harapannya, daerah ini menjadi daerah percontohan atas keberagaman kehidupan umat beragama yang tenteram. Pembinaan keimanan umat Hindu dilakukan melakukan apa yang disebut sebagai Darma Wacana, yaitu pencerahan rohani melalui diskusi dan tanya jawab kepada umat. Layaknya dakwah umat Islam, Darma Wacana dipusatkan di tempat-tempat ibadah (Pura).

Menyimak temuan lapangan di atas, dapat dipahami bahwa bentuk pelayanan keagamaan yang telah diberikan Kantor Kementerian Agama Kabupaten Luwu Utara tidak diperhadapkan dengan hal-hal yang dapat mengganggu kelancaran pemberian layanan publik kepada masyarakat, khususnya umat Hindu. Oleh karena itu, pemberian pelayanan yang dilakukan Kantor Kementerian Agama setempat sudah cukup dianggap distributif tanpa ada unsur-unsur politik, suku, ras dan agama tertentu, sebagaimana telah diamanatkan dalam mekanisme kerja Kantor Kementerian Agama secara nasional.

Namun demikian, mencermati temuan lapangan di atas kiranya perlu dipahami bahwa, secara subtantif faktor-faktor yang dapat memengaruhi suatu bentuk pelayanan publik pada umumnya terdiri dari dua sumber, yaitu apa yang disebut sebagai faktor internal dan faktor eksternal. Yang selanjutnya dapat dikemukakan secara teoritik yang dapat dilihat dari: faktor sumber daya manusia, faktor sarana dan prasarana, faktor mekanisme dan prosedur dan faktor koordinasi.

\section{Persepsi Umat Hindu terhadap Pelayanan Keagamaan}

Dalam wawancara dengan penganut agama Hindu setempat, diketahui bahwa pelayanan Kantor Kementerian Agama Kabupaten Luwu secara umum terfasilitasi melalui Bimas Hindu, yang dalam hal ini dilaksankaan oleh Bapak I Ketut Sukarna. Apaapa yang menjadi harapan umat pada dasarnya diserahkan kepada beliau untuk melakukan koordinasi program kegiatan keagamaan. Bentuk pelayanan yang dibutuhkan adalah pembinaan rohani umat melalui program-program keagamaan misalnya UDG (Upsawa Darma Gita). Rencananya bulan Juni 2014 akan datang dapat dilaksanakan.

Adapun bentuk dan kualitas pelayanan yang diberikan dianggap sudah cukup baik sesuai dan tepat sasaran sesuai dengan saran ajuan yang diharapkan umat melalui usulan ke Bimas Hindu. Terkait kebijakan keagamaan melalui penyebaran agama, umat Hindu pada dasarnya tidak melakukan penyebaran agama. Penguatan kerohanian hanya dilakukan melalui apa yang disebut sebagai Darma Wacana. Yaitu, suatu kegiatan semacam ceramah di umat Islam dipusatkan di Pura.

Dalam kaitannya dengan kualitas pelayan publik, terdapat beberapa faktor yang menyebabkan rendahnya kualitas pelayanan publik di Indonesia antara lain adanya: a) Konteks monopolistik, dalam hal ini karena tidak adanya kompetisi dari penyelenggara pelayanan publik non pemerintah, tidak ada dorongan yang kuat untuk meningkatkan jumlah, kualitas maupun pemerataan pelayanan tersebut oleh pemerintah, b) Tekanan dari lingkungan, dimana faktor lingkungan amat mempengaruhi kinerja organisasi pelayanan dalam transaksi dan interaksinya antara lingkungan dengan organisasi publik, c) Budaya patrimonial, dimana budaya organisasi penyelenggara pelayanan publik di Indonesia masih banyak terikat oleh tradisi- 
tradisi politik dan budaya masyarakat setempat yang seringkali tidak kondusif dan melanggar peraturanperaturan yang telah ditentukan.

Dalam hubungannya dengan peningkatan kualitas pelayanan publik, pemerintah telah menetapkan kebijakan tentang penerapan prinsipprinsip pelayanan publik sesuai Keputusan Menpan No. 63 Tahun 2004, meliputi: kesederhanaan, kejelasan, kepastian waktu, akurasi, keamanan, tanggung jawab, kelengkapan sarana dan prasarana, kemudahan akses, kedisiplinan, kesopanan dan keramahan, kenyamanan.

Tidak dapat disangkali bahwa agama Hindu merupakan salah satu agama tua yang ada di nusantara. Sejarah dengan terang mengukuhkan eksistensi keberadaannya. Terutama, ketika periode keemasan kerajaan Majapahit di Pulau Jawa. Oleh karena itu, tidak mengherankan apabila perkembangan kerajaan-kerajaan lainnya di nusantara juga tidak dapat dilepaskan darinya, termasuk dalam hal ini kerajaan-kerajaan yang tersebar dalam lingkup kedatuan Luwu. Pro kontra tentang latar agama dan kepercayaan masyarakat di kedatuan Luwu tentu saja dalam hal ini bukan menjadi pokok persoalan yang perlu diutarakan. Karena kajian ini bukan hendak digiring ke studistudi sejarah.

Dalam putaran waktu, agama Hindu cukup berkembang di Indonesia. Data terakhir yang diperoleh bahkan menunjukkan jumlah yang cukup besar mencapai 6,5 juta jiwa. Bahkan menurut hasil pencatatan Parisada Dharma Hindu Indonesia (PHDI) mencapai kurang lebih 18 juta jiwa, dan tersebar di pulau-pulau besar Indonesia, seperti Sumatra, Bali, Kalimantan, Nusa Tenggara, dan Sulawesi. Populasi terbesarnya berada di Pulau Bali.

Periode perkembangan agama Hindu selanjutnya memasuki babak baru di era Orde Baru, masa kepemimpinan Presiden Soeharto. Melalui program transmigrasi, umat Hindu banyak tersebar keluar pulau Jawa dan Bali. Jika melihat latar tujuan program transmigrasi, maka dapat diketahui bahwa penuntasan kemiskinan merupakan sasaran utamanya. Dengan kata lain, Tujuan resmi program ini adalah untuk mengurangi kemiskinan dan kepadatan penduduk di pulau Jawa, memberikan kesempatan bagi orang yang mau bekerja, dan memenuhi kebutuhan tenaga kerja untuk mengolah sumber daya di pulau-pulau lain seperti: Papua, Kalimantan, Sumatera, dan Sulawesi. Kritik mengatakan bahwa pemerintah Indonesia berupaya memanfaatkan para transmigran untuk menggantikan populasi lokal, dan untuk melemahkan gerakan separatis lokal. Program ini beberapa kali menyebabkan persengketaan dan percekcokan, termasuk juga bentrokan antara pendatang dan penduduk asli setempat.

Seiring dengan perubahan lingkungan strategis di Indonesia, transmigrasi dilaksanakan dengan paradigma baru untuk mendukung ketahanan pangan dan penyediaan papan; mendukung kebijakan energi alternatif (bio-fuel); mendukung pemerataan investasi ke seluruh wilayah Indonesia; mendukung ketahanan nasional pulau terluar dan wilayah perbatasan; dan menyumbang bagi penyelesaian masalah pengangguran dan kemiskinan.

Transmigrasi tidak lagi merupakan program pemindahan penduduk, melainkan upaya untuk pengembangan wilayah. Metodenya tidak lagi bersifat sentralistik dan top down dari Jakarta, melainkan berdasarkan Kerjasama Antar daerah pengirim transmigran dengan daerah tujuan transmigrasi. Penduduk setempat semakin diberi kesempatan besar untuk menjadi transmigran penduduk setempat (TPS), proporsinya hingga mencapai 50:50 dengan transmigran Penduduk Asal (TPA).

Dasar hukum yang digunakan untuk program ini adalah Undang-Undang Republik Indonesia Nomor 15 Tahun 1997 tentang Ketransmigrasian (sebelumnya UU Nomor 3 Tahun 1972) dan Peraturan Pemerintah Republik Indonesia Nomor 2 Tahun 1999 tentang Penyelenggaraan Transmigrasi (Sebelumnya PP Nomor 42 Tahun 1973), ditambah beberapa Keppres dan Inpres pendukung.

Program transmigrasi tidak dapat pula dipisahkan dari isu-isu seputar pelayanan publik, karena bersentuhan langsung dengan masyarakat luas, baik itu sifatnya bersumber dari daerah asal keberangkatan sampai pada daerah tujuan/ penempatan, terlebih dalam konteks sistem desentralisasi yang berkembang secara nasional sejauh ini.

Sudah sejak lama banyak kesan buruk yang disandang aparat pemerintah (sektor publik) dalam hal pelayanan. Hal ini antara lain dapat diindikasikan dari besarnya dana yang digunakan untuk membiayai aparatur pemerintah, namun hal itu ternyata tidak diimbangi dengan kualitas pelayanan kepada masyarakat yang maksimal. Bahkan sebaliknya, kualitas pelayanan yang diberikan instansi pemerintah dapat dinilai sangat buruk. Padahal masyarakat telah bersedia 
mengorbankan (sacrifice) sebagian sumber dayanya untuk negara dengan membayar berbagai macam pungutan, baik pajak, retribusi dan sebagainya. Sudah sewajarnya jika masyarakat mengharapkan kepuasan (satisfaction) yang maksimal atas pelayanan yang diberikan oleh negara. Namun apa yang diperoleh masyarakat adalah buruknya kualitas pelayanan instansi pemerintah.

Salah satu keluhan masyarakat yang sering terungkapkan adalah lambatnya waktu pelayanan dan tidak jelasnya prosedur dan biaya pelayanan. Ungkapan-ungkapan yang berkembang selama ini, seperti "kalau bisa dilakukan besok kenapa harus sekarang? "kalau bisa dipersulit kenapa harus dipermudah?" menunjukkan bahwa budaya pelayanan pada instansi pemerintahan masih belum berorientasi pada kepuasan masyarakat selaku pelanggannya. Hal yang demikian bukan saja mengakibatkan pemborosan sumberdaya tetapi juga kualitas jasa yang dihasilkan menjadi sangat buruk.

Sektor publik (pemerintahan) pada dasarnya adalah perusahaan yang menghasilkan produk berupa jasa pelayanan publik, baik pelayanan yang bersifat langsung dinikmati oleh masyarakat maupun pelayanan yang dinikmati masyarakat secara tidak langsung. Namun demikian, pemerintah tidak bermaksud mengambil keuntungan dari operasionalnya. Salah satu prinsip dalam pelaksanaan tugas instansi pemerintah adalah transparansi dan pertanggungjawaban kepada publik atas apa yang telah dilakukan. Hal ini sesuai dengan prinsip tata kelola pemerintahan yang baik (good governance), yang terdiri dari tiga prinsip utama, yaitu transparansi, partisipasi dan akuntabilitas. Namun demikian tampaknya pemerintah belum sepenuhnya mampu menerapkan ketiga pilar utama tersebut dalam pelayanan. Dengan kondisi demikian, seandainya negara sebagai penyedia layanan harus bersaing dengan swasta dengan produk pelayanan yang sama, dapat diperkirakan bahwa secara perlahan namun pasti negara akan bangkrut karena biaya produksi sangat tinggi, sedang pendapatan akan berkurang drastis akibat ditinggalkan oleh para pelanggan yang tidak puas dengan pelayanan yang diberikan.

Bergulirnya era reformasi sebagai dampak krisis multidimensi yang melanda negara kita telah melahirkan tuntutan perubahan yang juga bersifat multidimensional. Krisis multidimensi tersebut berpengaruh terhadap kemampuan negara dalam aspek keuangan. Pada sisi lain kompleksitas pelayanan publik yang dibutuhkan masyarakat baik secara kuantitatif maupun kualitatif meningkat secara tajam tanpa diimbangi dengan peningkatan keuangan daerah untuk membiayainya. Akibatnya pelayanan publik menjadi terbengkalai seperti rusaknya sarana dan prasarana transportasi, saluran irigasi, pendidikan serta kesehatan baik secara kualitatif maupun kuantitatif.

Menurunnya kinerja ekonomi secara keseluruhan akan sangat berpengaruh terhadap penerimaan daerah baik yang berasal dari Pendapatan Asli Daerah (PAD) maupun yang berasal dari Pusat dalam bentuk Dana Alokasi Umum (DAU) maupun Dana Alokasi Khusus (DAK). Kondisi tersebut memunculkan kebutuhan yang sangat mendesak bagi sektor publik di daerah (Pemda) untuk melibatkan sektor swasta dan masyarakat dalam pemenuhan pelayanan publik yang meningkat dalam kondisi keuangan daerah yang terpuruk. Hal ini seiring dengan argumen Osborne dan Gabler yang menganjurkan pemerintah untuk lebih berperan dalam mengendalikan (steering) dibandingkan menangani langsung (rowing). Dalam hal ini, pemerintah harus mampu menjadi katalisator bagi keterlibatan pihak swasta dan masyarakat untuk ikut berpartisipasi dalam menyediakan pelayanan publik. Implementasi pelibatan swasta dan masyarakat dalam pelayanan publik kemudian mendapatkan legitimasi dengan penerapan otonomi daerah.

Pelayanan keagamaan yang juga masih bagian dari bentuk pelayanan publik dalam konteks era desentralisasi ini. Oleh karena itu, pelayanan publik seharusnya menjadi lebih responsif terhadap kepentingan publik. Paradigma pelayanan publik berkembang dari pelayanan yang sifatnya sentralistik ke pelayanan yang lebih memberikan fokus pada pengelolaan yang berorientasi kepuasan pelanggan dengan ciri-ciri: 1) Lebih memfokuskan diri pada fungsi pengaturan melalui berbagai kebijakan yang memfasilitasi berkembangnya kondisi kondusif bagi kegiatan pelayanan kepada masyarakat. 2) Lebih memfokuskan diri pada pemberdayaan masyarakat sehingga masyarakat mempunyai rasa memiliki yang telah dibangun bersama. 3) Menerapkan sistem kompetisi dalam hal penyediaan pelayanan publik tertentu sehingga masyarakat memperoleh pelayanan yang berkualitas. 4) Terfokus pada pencapaian visi, misi, tujuan, dan sasaran yang berorientasi pada hasil (outcomes) sesuai dengan masukan yang digunakan. 5) Lebih mengutamakan apa yang diinginkan oleh masyarakat. Dan 6) Pada hal tertentu pemerintah juga berperan untuk 
memperoleh pendapatan dari masyarakat dari pelayanan yang dilaksanakan.

Permasalahan utama pelayanan publik pada dasarnya adalah berkaitan dengan peningkatan kualitas pelayanan itu sendiri. Pelayanan yang berkualitas sangat tergantung pada berbagai aspek, yaitu bagaimana pola penyelenggaraannya (tata laksana), dukungan sumber daya manusia, dan kelembagaan. Dilihat dari sisi pola penyelenggaraannya, pelayanan publik masih memiliki berbagai kelemahan antara lain:

Kurang responsif. Kondisi ini terjadi pada hampir semua tingkatan unsur pelayanan, mulai pada tingkatan petugas pelayanan (front line) sampai dengan tingkatan penanggung jawab instansi. Respon terhadap berbagai keluhan, aspirasi, maupun harapan masyarakat seringkali lambat atau bahkan diabaikan sama sekali. Responsivitas atau daya tanggap adalah kemampuan organisasi untuk mengidentifikasi kebutuhan masyarakat, menyusun prioritas kebutuhan, dan mengembangkannya ke dalam berbagai program pelayanan. Responsivitas mengukur daya tanggap organisasi terhadap harapan, keinginan dan aspirasi, serta tuntutan warga pengguna layanan. Tujuan utarna pelayanan publik adalah memenuhi kebutuhan warga pengguna agar dapat memperoleh pelayanan yang diinginkan dan memuaskan. Karena itu, penyedia layanan harus mampu mengidentifikasi kebutuhan dan keinginan warga pengguna, kemudian memberikan pelayanan sesuai dengan keinginan dan kebutuhan warga tersebut. Beberapa pakar manajemen, seperti Peters dan Waterman, serta Drucker dan Deming, menempatkan pentingnya mendengarkan aspirasi pelanggan atau pengguna. Mereka memberikan nasehat kepada para manajer untuk mempertemukan karyawan rnereka secara langsung dengan pelanggan. Hewlett-Packard merminta para pelanggan untuk membuat presentasi yang menggambarkan kebutuhan mereka (Osborne dan Gaebler, 1996: 194). Untuk meningkatkan responsivitas organisasi terhadap kebutuhan pelanggan, terdapat dua strategi yang dapat digunakan, yaitu menerapkan strategi KYC (know your customers) dan menerapkan model citizen's char tier.

Kurang informatif. Berbagai unit pelaksana pelayanan terletak jauh dari jangkauan masyarakat, sehingga menyulitkan bagi mereka yang memerlukan pelayanan tersebut.

Kurang koordinasi. Berbagai unit pelayanan yang terikat satu dengan lainnya sangat kurang berkoordinasi, akibatnya sering terjadi tumpang tindih ataupun pertentangan kebijakan antara satu instansi pelayanan dengan instansi pelayanan lain yang terkait.

Birokrasi. Pelayanan (khususnya pelayanan perizinan) pada umumnya dilakukan dengan melalui proses yang terdiri dari berbagai level sehingga menyebabkan penyelesaian masalah pelayanan, kemungkinan staf pelayan (front line staff) untuk dapat menyelesaikan masalah sangat kecil, dan di lain pihak kemungkinan masyarakat untuk bertemu dengan penanggung jawab pelayanan, dalam rangka menyelesaikan masalah yang terjadi ketika pelayanan diberikan, juga sangat sulit.

Uraian di atas mengindikasikan kearah pemenuhan efisiensi layanan publik. Oleh karena itu, efisiensi dalam pelayanan publik dapat dilihat dari perspektif pemberi layanan maupun pengguna layanan. Dari perspektif pemberi layanan, organisasi pemberi layanan harus mengusahakan agar harga pelayanan murah dan tidak terjadi pemborosan sumber daya publik. Pelayanan publik sebaiknya melibatkan sedikit mungkin pegawai dan diberikan dalam waktu yang singkat. Demikian juga dari perspektif pengguna layanan, mereka menghendaki pelayanan publik dapat dicapal dengan biaya yang murah, waktu singkat, dan tidak banyak membuang energi.

\section{PENUTUP}

Berdasarkan data dan fakta serta informasi yang telah dikemukakan pada bab-bab terdahulu sebagai jawaban atas permasalahan utama yang didalami dalam penelitian ini, dapat disimpulkan bahwa cukup besarnya populasi umat Hindu yang mencapai 10330 orang (Bimas Hindu, 2012) kiranya perlu mendapat perhatian serius dalam pemberian pelayanan publik oleh Kantor Kementerian Agama Kabupaten Luwu Utara. Perlunya peningkatan pelayanan keagamaan kepada penganut agama (secara khusus kepada umat Hindu) pada hakikatnya adalah: suatu upaya untuk mempererat integritas dan kohesi sosial, mengingat heterogenitas masyarakat di Kabupaten Luwu Utara dapat berakibat timbulnya konflik secara manifest; peningkatan kesadaran dan arti pentingnya solidaritas sosial antar umat beragama guna mereduksi kemungkinan konflik horizontal dalam masyarakat yang bisa terjadi sewaktu-waktu; dan memberdayakan kehidupan umat beragama dengan serangkaian program dan kegiatan semisal pawai budaya untuk meningkatkan kualitas layanan keagamaan kepada seluruh umat 
beragama di lingkup Kabupaten Luwu Utara.

Terdapat empat hal pokok yang dapat memengaruhi kualitas layanan keagamaan, yaitu: faktor sumber daya manusia; faktor sarana dan prasarana, faktor mekanisme dan prosedur; dan faktor koordinasi. Berdasarkan keempat hal tersebut, maka peningkatan sumber daya manusia mutlak diperlukan guna mewujudkan kesadaran atas heterogenitas agama yang perlu saling harga menghargai. Sarana dan prasarana dalam arti pendirian rumah ibadah diharapkan tidak mendapat pembatasan sehingga umat dalam mengeskpresikan dan mengaktualisasikan tata cara peribadatan yang menjadi kewajiban dalam kepercayaan agamanya. Pelayanan dilakukan dalam satuan mekanisme dan prosedur tertentu dengan menerapkan prinsipprinsip kemudahan akses bagi penganut agama Hindu. Sedangkan koordinasi dalam hal ini Bimas Hindu senantiasa membangun komunikasi aktif dalam upayanya memfasilitasi kebutuhan umat Hindu terhadap pelayanan keagamaan yang diperlukan.

Pelayanan keagamaan yang diterima penganut agama Hindu telah sesuai dengan mekanisme dan prosedur layanan, yang kesemuanya terfasilitasi oleh Bimas Hindu Kantor Kementerian Agama Kabupaten Luwu Utara.

\section{UCAPAN TERIMA KASIH}

Hadirnya tulisan ini tidak lepas dari banyak pihak yang telah memberi kontribusi yang sangat membantu hingga dapat selesai pada waktunya. Karena itu kami sangat berterima kasih kepada semua pihak yang telah memberikan bantuannya, terutama kepada informan di Kementerian Agama Kabupaten Luwu Utara, Bimas Hindu, dan umat
Hindu Masamba, Kabupaten Luwu Utara. Semoga informasi yang kami himpun dalam tulisan ini dapat bermanfaat bagi konsep pelayanan umat beragama kedepan.

\section{DAFTAR PUSTAKA}

Badan Pusat Statistik. 2010. Luwu Utara Dalam Angka. Kabupaten Luwu Utara.

Endraswara, Suwardi.2006. Metode, Teori, Teknik Penelitian Kebudayaan. Ideologi, Epistemologi, dan Aplikasi. Yogyakarta: Pustaka Widyatama. http://id.wikipedia.org/ wiki/pelayanan_publik, diakses pada 21 Desember 2012.

Kepmenpan Nomor 63/KEP/M.PAN/7/2003 tentang Pelayanan Publik

Miles dan Huberman. 1994 Qualitative Data analysis, A. Sourcebook of new methods, Veverly Hills: Sage publication

Moleong, Lexi J. 2000. Metode Penelitian Kualitatif. Bandung: Rosda Karya.

Pat Badrun dkk.. 2008. Optimalisasi Pelayanan Keagamaan Departemen Agama. Makassar: Indobis Publishing.

Ratminto dan Atik SP. 2007. Manajemen Pelayanan, Pengembangan Model Konseptual, Penerapa Citizen's Charter dan Standar Pelayanan Mutu. Jogjakarta: Pustaka Pelajar.

Rentra Badan Litbang dan Diklat Kementerian Agama 2010-2014. 2010. Penerbit Badan Litbang dan Diklat Kementerian Agama, Jakarta.

Sutopo dan Adi Suryanto. 2009. Pelayanan Prima. Jakarta: Lembaga Administrasi Negara Republik Indonesia. 